\author{
Rafat Kubicki \\ https://orcid.org/0000-0002-217I-5713 \\ Instytut Historii \\ Uniwersytetu Gdańskiego
}

\title{
Mendykanci wobec reformacji w Prusach Królewskich i Zakonnych do 1526 roku*
}

Celem artykułu jest próba prześledzenia reakcji wspólnot mendykanckich na wydarzenia związane z wystąpieniem Marcina Lutra. Problem ten zaprezentowano na przykładzie klasztorów w Prusach Krzyżackich i Zakonnych. Jako datę końcową opracowania przyjęto rok 1526. Obok perspektywy dziejów instytucjonalnych poszczególnych zgromadzeń zagadnienie to przedstawione zostało również z punktu widzenia szeregowych zakonników oraz ich indywidualnych decyzji i motywacji.

The goal of the article is an attempt to follow the reaction of mendicant communities to the events connected with Luther's theses. This problem is presented based on the example of monasteries in Royal and Teutonic Prussia. As the final date of the study the author chose the year 1526. Besides the perspective of the institutional history of particular orders the problem is also presented from the point of view of ordinary monks and their individual decisions and motivations.

* Tekst referatu wygłoszonego na konferencji: „Jubileusz Pięćsetlecia Reformacji (1517-2017). Protestantyzm w Prusach Królewskich i Książęcych. Historia Ludzie - Sztuka - Literatura”, zorganizowanej przez Instytut Historii i Instytut Historii Sztuki Uniwersytetu Gdańskiego oraz Instytut Historii PAN w Gdańsku 29-30 IX 2017 r. Przebieg reformacji, a przede wszystkim jej skutki, w wymiarze instytucjonalnym i personalnym, dla funkcjonowania klasztorów mendykanckich w Prusach Krzyżackich i Królewskich aż do drugiej połowy XVI w. przedstawione zostały w: R. Kubicki, Zakony mendykanckie w Prusach Krzyżackich i Królewskich od XIII do potowy XVI wieku, Gdańsk 2018, s. 289-320. W tym miejscu nawiązuję do przedstawionych w tej pracy tez. 
Słow a klu c z o w e: reformacja, Prusy Zakonne, Prusy Królewskie, zakony mendykanckie, zakony mnisze

Keywo rds: Reformation, Teutonic Prussia, Royal Prussia, mendicant orders, monastic orders

Wydarzenia związane z początkami reformacji skutkowały wieloma reakcjami poszczególnych społeczności, których skala i intensywność była zróżnicowana. W największym stopniu oddziaływały oczywiście na sytuację osób tworzących struktury instytucjonalne Kościoła, a więc duchownych diecezjalnych i zakonników, a w konsekwencji również na stan istniejących na danym terenie klasztorów. Można wręcz stwierdzić, że klasztory należały do instytucji najbardziej podatnych na zmiany, które niosły za sobą te wydarzenia ${ }^{1}$. Wynikało to $\mathrm{z}$ faktu zaangażowania się zakonników w ruch reformy. W tym zakresie szczególną rolę odegrali przedstawiciele zakonów mendykanckich.

W związku z tym wydaje się, że ważne jest prześledzenie reakcji wspólnot zakonów mendykanckich na wydarzenia następujące po wystąpieniu Marcina Lutra, który sam również wywodził się z tych środowisk, jako członek zakonu augustianów-eremitów ${ }^{2}$. W tym miejscu problem ten przedstawiony zostanie na przykładzie terenu Prus Królewskich i Zakonnych ${ }^{3}$. Jako datę końcową opracowania przyjęto

1 E. Wolgast, Die Einführung der Reformation und das Schicksal der Klöster im Reich und in Europa, Gütersloh 2015 (Quellen und Forschungen zur Reformationsgeschichte, Bd. 89).

2 Na temat stosunku Lutra do życia monastycznego i stopniowej ewolucji jego poglądów zob. H.-M. Stamm, Luthers Stellung zum Ordensleben, Wiesbaden 1980 (Veröffentlichungen des Instituts für Europäische Geschichte Mainz, Bd. 101); E. L. Saak, Martin Luther and the Monastic World of the Later Middle Ages, w: Oxford Research Encyclopedia of Religion, http://religion.oxfordre.com/ (2 II 2017); J. M. Todd, Reformacja, tł. J. S. Łoś, T. Szafrański, Warszawa 1974, s. 204-213. W literaturze polskiej, z przywołaniem najnowszego stanu badań nad problemem, kwestię tę przedstawiła G. Wąs, Teoria i praktyka życia klasztornego na terenach protestanckich $w$ okresie nowożytnym, w: Kasaty klasztorów na obszarze dawnej Rzeczypospolitej Obojga Narodów i na Ślasku na tle procesów sekularyzacyjnych w Europie, t. 1: Geneza kasaty na ziemiach zaborów austriackiego i rosyjskiego, red. M. Derwich, Wrocław 2014, s. 43-59.

3 Ogólnie nt. początków reformacji w Prusach Królewskich i Krzyżackich zob. J. Małłek, Rozwój reformacji na Pomorzu, w: idem, Opera selecta, t. 4: Reformacja i protestantyzm w Polsce i Prusach (XVI-XX w.), Toruń 2012, s. 120-132; idem, Poczatki protestantyzmu w Prusach Ksiązęcych (sekularyzacja państwa zakonu krzyżackiego w Prusach a problem ponownej ewangelizacji), w: ibidem, s. 230-240; 
rok 1526. Nie stanowi ona wprawdzie ogólnej cezury z punktu widzenia wewnętrznych dziejów poszczególnych zgromadzeń mendykanckich, ale przyjmowana jest dla lokalnych dziejów ruchu reformacyjnego. Związana jest bowiem z formalną reakcją na działania zwolenników reformacji, podjętą wówczas przez dwór królewski, a następnie również biskupów warmińskiego i włocławskiego, którzy wystąpili oficjalnie przeciw duchownym wspierającym nowy ruch, w tym też wielu zakonnikom i zakonnicom, porzucającym swe wspólnoty zakonne ${ }^{4}$. Obok perspektywy dziejów instytucjonalnych poszczególnych zgromadzeń zagadnienie to przedstawione zostanie również z punktu widzenia szeregowych zakonników oraz ich indywidualnych decyzji i motywacji. Podstawą będzie przede wszystkim zachowana korespondencja pomiędzy poszczególnymi klasztorami, głównie franciszkańskimi.

Klasztory mendykanckie w Prusach Królewskich i Zakonnych oraz ich losy w pierwsych latach rozwoju reformacji

$\mathrm{Na}$ terenie Prus Krzyżackich i Królewskich w chwili wystąpienia Lutra istniały łącznie 23 klasztory mendykanckie, w tym 16 w Prusach Królewskich i 7 w Prusach Zakonnych. Było wśród nich: 7 konwentów franciszkanów ${ }^{5}, 6$ konwentów dominikanów, 5 konwentów franciszkanów obserwantów, 4 konwenty augustianów-eremitów i 1 konwent karmelitów ${ }^{6}$. W większości były to fundacje zrealizowane

J. Możdżeń, The Beginnings of the Reformation in the Light of Gdańsk and Königsberg Chroniclers of the First Half of the $16^{\text {th }}$ Century, "Zapiski Historyczne”, 82, 2017, 1, s. 75-77.

4 Rywalizacja katolików z luteranami o kościót św. Mikotaja w Elblagu 1520-1621. Źródta do dziejów reformacji w Prusach Królewskich, zebr. i oprac. A. Szorc, Olsztyn 2002.

5 Warto dodać, że w następstwie realizowanych od 1517 r. prób zjednoczenia różnych nurtów obecnych w zakonie franciszkanów obradująca w 1518 r. we Frankfurcie nad Odrą wspólna kapituła prowincjalna saskich obserwantów i franciszkanów konwentualnych podjęła decyzję o zawarciu ich formalnej unii. Przy czym konwenty obserwantów utworzyły prowincję saską Świętego Krzyża, natomiast konwentualne prowincję saską św. Jana Chrzciciela; zob. Spuren franziskanischer Geschichte. Chronologischer Abriß der Geschichte der Sächsischen Franziskanerprovinzen von ihren Anfängen bis zur Gegenwart, bearb. B. Schmies, K. Rakemann, hrsg. D. Berg, Werl 1999 (Saxonia Franciscana, Sonderband), s. 249.

6 R. Kubicki, Die Rolle der Bettelorden im Ordensland Preußen, w: Cura animarum, Seelsorge im Deutschordensland des Mittelalters, hrsg. S. Samerski, 
w XIII i XIV w., od dawna funkcjonujące w środowisku społecznym poszczególnych ośrodków miejskich. Do nowych, powstałych na krótko przed reformacją, można zaliczyć jedynie konwenty franciszkanów obserwantów w Lubawie z 1502 r., Tylży z 1516 r. i w Królewcu, gdzie bracia trafili z Welawy dopiero w 1517 r. Patrząc na problem od strony instytucjonalnej, dalsze losy klasztorów były wynikiem decyzji podejmowanych zazwyczaj przez czynniki polityczne, względnie przemian dokonujących się pod wpływem reformacji w obrębie poszczególnych zgromadzeń zakonnych i reakcji miejscowych środowisk mieszczańskich. W przypadku klasztorów istniejących na terenie Prus Krzyżackich ich likwidacja w 1525 r. była bezpośrednim następstwem decyzji ostatniego wielkiego mistrza zakonu krzyżackiego Albrechta Hohenzollerna, który doprowadził nie tylko do sekularyzacji istniejących tam wciąż, choć w formie szczątkowej, struktur zakonu krzyżackiego, ale również wszystkich klasztorów należących do innych zgromadzeń zakonnych, głównie mendykantów ${ }^{7}$. W ten sposób na skutek decyzji politycznych księcia Albrechta, wyrażających się m.in. w przyjęciu nowego modelu zreformowanego chrześcijaństwa, dodajmy, programowo odrzucającego wszelkie formy życia zakonnego, nastąpiła likwidacja wszystkich klasztorów istniejących do tego czasu na terenie Prus Krzyżackich. W tym kontekście inna była sytuacja klasztorów mendykantów w biskupstwie warmińskim i na terenie Prus Królewskich ${ }^{8}$. Czynnik polityczny, w postaci polskiego dworu królewskiego, opowiadał się za zachowaniem status quo, klasztory mogły więc liczyć na pewne wsparcie. Jednak w przypadku funkcjonujących w miastach klasztorów mendykanckich w dłuższej perspektywie równie ważne były decyzje elit rządzących i postawa miejscowej ludności. Tam gdzie liczącą siłą stawali się zwolennicy reformacji stopniowo dochodziło też do prób całkowitej likwidacji klasztorów. Wprawdzie nie nastąpiło to w pierwszym okresie, do 1526 r., ale już wówczas klasztory zlokalizowane w miastach znalazły się w bardzo głębokim kryzysie organizacyjnym i personalnym,

Köln-Weimar-Wien 2013 (Forschungen und Quellen zur Kirchen- und Kulturgeschichte Ostdeutschlands, Bd. 45), s. 74-91.

7 M. Biskup, Średniowieczna sieć klasztorów w państwie zakonu krzyżackiego w Prusach (do 1525 r.), „Zapiski Historyczne”, 64, 1999, 1, s. 58-59.

8 Ogólnie nt. sytuacji klasztorów na Warmii w początkach reformacji zob. A. Kopiczko, Reformacja na Warmii - uwarunkowania i zakres oddziatywania (do 1530 r.), w: Dysydenci czy decydenci? Protestanci w obu częściach Prus i Koronie w XVI-XVIII wieku, red. W. Zawadzki, Elbląg 2018, s. 93-95, 103. 


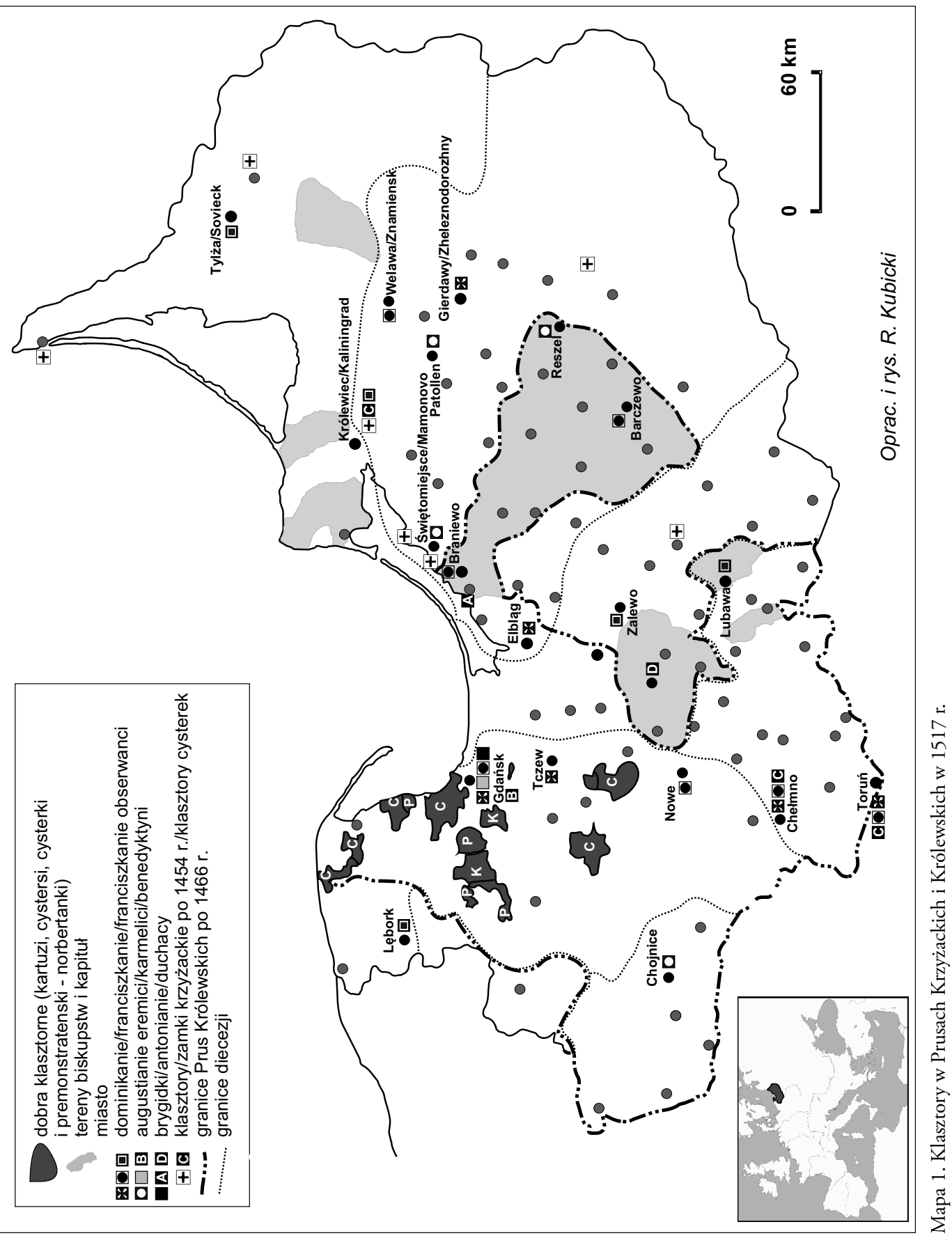


zazwyczaj nie mogąc też liczyć na pomoc ze strony własnych prowincji zakonnych ${ }^{9}$. Tak zarysowany nieco ogólny przegląd losów klasztorów w pierwszych latach reformacji spróbujmy zilustrować na kilku lepiej oświetlonych źródłowo przykładach, co pozwoli nie tylko przedstawić szczegółowy kontekst tych wydarzeń, ale również indywidualne decyzje zakonników.

Sytuacja wewnętrzna konwentów przed 1517 r. i reakcje zakonników na pierwsze wystąpienia zwolenników reformacji

Chcąc rozpatrzyć interesujący nas problem we właściwym kontekście, na wstępie wypada określić stan wewnętrzny poszczególnych zgromadzeń i ich konwentów w drugim dziesięcioleciu XVI w., w skali całej prowincji zakonnej i lokalnych warunków, panujących w Prusach Królewskich i Zakonnych. Sytuacja poszczególnych klasztorów w tym

9 W późniejszym czasie dominikanie trwale utracili konwent w Elblągu (po 1542), a długo puste stały ich klasztory w Tczewie i Chełmnie; R. Kubicki, Srodowisko dominikanów kontraty pruskiej od XIII do potowy XVI wieku, Gdańsk 2007, s. 42. Franciszkanie konwentualni z prowincji saskiej opuścili wszystkie swe klasztory: w Gdańsku (po 1555), Braniewie (w 1565 r. objęli go jezuici), Barczewie (w 1597 r. objęli go polscy bernardyni); Urkundenbuch des alten sächsischen Franziskanerprovinzen, t. 1: Die Observantenkustodie Livland und Preussen, t. 2: Die Kustodie Preussen, hrsg. L. Lemmens, Düsseldorf 1913 (dalej: USF I, II), nr 633, s. 167. Opuszczony klasztor franciszkanów konwentualnych w Nowem nad Wisłą w 1604 r. objęli polscy bernardyni; H. Maercker, Eine polnische Starostei und ein preussischer Landrathskreis. Geschichte des Schwetzer Kreises 1466-1873, „Zeitschrift des Westpreußischen Geschichtsvereins”, 19, 1888, s. 130. Klasztor w Toruniu bracia opuścili w 1559 r., a w 1724 r. wrócili do niego polscy bernardyni; USF II, nr 611, s. 161; T. Glemma, Dzieje stosunków kościelnych w Toruniu, w: Dzieje Torunia. Praca zbiorowa z okazji 700-lecia miasta, red. K. Tymieniecki, Toruń 1933, s. 290. Opustoszał także klasztor augustianów-eremitów w Chojnicach. W 1624 r. odzyskali go jednak bracia z prowincji polskiej; Z. Kratochwil, Augustianie w Chojnicach (1356-1819), „Rocznik Gdański”, 49, 1989, 1, s. 26-32. Z kolei ich klasztor w Reszlu, który pusty był od 1524 r., w 1630 r. objęli jezuici; A. Poschmann, Das Augustinerkloster in Rössel, „Zeitschrift für die Geschichte und Altertumskunde Ermlands”, 24, 1932, s. 134. Swe placówki utracili również franciszkanie obserwanci z prowincji saskiej. Ich klasztor w Lubawie stał pusty od 1566 r., aż do przejęcia go w 1580 r. przez polską prowincję bernardynów; USF I, nr 365, s. 81. Zlikwidowany został także konwent w Lęborku; zob. H. Hoogeweg, Die Stifter und Klöster der Provinz Pommern, Bd. 2, Stettin 1925, s. 109. Co ciekawe, w 1640 r. podjęto próbę osadzenia w miejscu dawnego klasztoru obserwantów zakonu pijarów; USF I, nr 370, s. 82. Po 1657 r. wraz $\mathrm{z}$ odpadnięciem tych ziem od Rzeczypospolitej sprawa ta ostatecznie upadła. 
czasie wydawała się względnie dobra. Przypomnijmy, że pod koniec XV i w początkach XVI w. przeprowadzono reformę życia wewnętrznego większości tutejszych klasztorów ${ }^{10}$. W przypadku dominikanów potwierdzeniem jej skuteczności była działalność studium partykularnego w konwencie gdańskim, dokąd kolejne kapituły prowincji kierowały licznych studentów ${ }^{11}$. Z kolei reformę klasztorów franciszkańskich w Gdańsku i Toruniu, odwołując się do konstytucji Marcina V (tzw. Martiniani), stosowanej przez franciszkanów konwentualnych na terenie prowincji saskiej zakonu, wprowadzono tu w $1491 \mathrm{r}^{12} \mathrm{~W}$ późniejszym czasie reformą objęto również ich klasztory w Barczewie ${ }^{13}$ i Nowem nad Wisłą ${ }^{14}$. Podobna reforma dotyczyła również klasztoru karmelitów w Gdańsku ${ }^{15}$ i augustianów-eremitów, których konwenty, podobnie jak i inne klasztory prowincji sasko-turyńskiej augustianów, zaliczone zostały do saskiej kongregacji obserwanckiej, na czele której stał Jan von Staupitz (wikariusz kongregacji zreformowanych

10 R. Kubicki, Zakony mendykanckie, s. 258-265.

$11 \mathrm{Na}$ kolejnych kapitułach prowincji (1501 r. Cieszyn, 1505 r. Poznań, 1512 r. Bochnia); Acta capitulorum Provinciae Poloniae Ordinis Praedicatorum, vol. 1: 1225-1600, ed. R. F. Madura, Roma 1972, s. 136, 154-155, 191.

12 USF II, nr 473, 474; F. Doelle, Die Martinianische Reformbewegung in der Sächsischen Franziskanerprovinz (Mittel- und nordostdeutschland) im 15. und 16. Jahrhundert, Münster 1921, s. 37, 78-79; K. Kantak, Franciszkanie polscy, t. 1, Kraków 1937, s. 358-361; nt. reformy prowadzonej w prowincji saskiej zakonu franciszkanów zob. P. L. Nyhus, The Franciscan Observant Reform in Germany, w: Reformbemühungen und Observanzbestrebungen im spätmittelalterlichen Ordenwesen, hrsg. K. Elm, Berlin 1989 (Berliner Historische Studien, Bd. 14, Ordenstudien, 6), s. 207-217; P. Weigel-Schieck, Landesherren und Observanzbewegung. Studien zur Reformverständnis des sächsischen Provinzialminister Matthias Döring (1427-1461), w: Könige, Landesherren und Bettelorden. Konflikt und Kooperation in West- und Mitteleuropa bis zur Frühen Neuzeit, hrsg. D. Berg, Werl 1998 (Saxonia Franciscana Beiträge zur Geschichte der Sächsischen Franziskanerprovinz, Bd. 10), s. 361-390.

13 Wówczas to zakonnicy formalnie przekazali bp. Łukaszowi Watzenrode cały majątek klasztoru, otrzymując jednocześnie prawo do jego dalszego użytkowania; USF II, nr 482, s. 129; K. Kantak, op. cit., s. 360.

14 Na prośbę kustosza kustodii pruskiej król Zygmunt I 17 VIII 1520 r. przejął formalnie cały majątek klasztoru, zezwalając braciom na jego wieczyste użytkowanie; USF II, nr 521, s. 136; K. Kantak, op. cit., s. 360; dok. opublikował H. Maercker, op. cit., dok. XVII, s. 392-395.

15 R. Kubicki, Próby reformy konwentu gdańskiego dominikanów na tle reformy innych klasztorów mendykanckich Prus Królewskich w XV w., w: Ecclesia semper reformanda. Kryzysy i reformy średniowiecznego Kościota, red. T. Gałuszka, T. Graff, G. Ryś, Kraków 2013, s. 529. 
klasztorów w latach $1503-1520)^{16}$. Tak więc w przededniu reformacji miejscowe klasztory mendykantów były poddane obserwancji i wydawało się, że przebywający w nich zakonnicy z pełnym przekonaniem realizowali swe powołanie zakonne ${ }^{17}$.

Sytuacja zmieniła się jednak radykalnie w ciągu kilku kolejnych lat, o czym przesądziły zarówno czynniki zewnętrzne, jak i decyzje podejmowane przez samych zakonników. Oczywiście miało to ścisły związek z faktem, że zwolennicy reformy życia kościelnego wywodzili się w dużej liczbie spośród byłych zakonników ${ }^{18}$. Idąc tym samym za Lutrem, który sam porzucił wspólnotę augustianów-eremitów. Przypomnijmy, że najpierw w 1520 r. zakwestionował on rolę zakonów mendykanckich i wartość ślubów zakonnych (w apelu do szlachty chrześcijańskiej z maja 1520 i traktacie $O$ ślubach zakonnych - De votis monasticis z grudnia 1520, ogłoszonym w roku następnym), by w $1524 \mathrm{r}$. określić klasztory jako instytucje zagrażające duszom ich mieszkańców, a 9 października tego roku ostatecznie

16 G. Uth, Szkic historyczno-biograficzny zakonu augustjańskiego w Polsce, Kraków 1930, s. 54; A. Poschmann, op. cit., s. 117; nt. reform klasztorów i ruchu obserwanckiego u augustianów-eremitów zob. F. Andrews, The Other Friars. The Carmelite, Augustinian, Sack and Pied Friars in the Middle Ages, Woodbridge 2006, s. 163-171; A. Kunzelmann, Geschichte der deutschen Augustiner-Eremiten, t. 5: Die Sächsisch-Thüringische Provinz und die Sächsische Reformkongregation bis zum Untergang der Beiden, Würzburg 1974, s. 387-466.

17 Pewne zamieszanie w przypadku franciszkanów mogły jednak wywołać decyzje podjęte w 1517 r. przez papieża Leona X. Kapituła generalna zakonu w Rzymie zamiast doprowadzić do zjednoczenia utrwaliła podział zakonu na dwie odrębne gałęzie: obserwancką i konwentualną, co papież potwierdził bullą Ite et vos in vineam meam; J. Moorman, A History of the Franciscan Order from its Origins to the Year 1517, Oxford 1968, s. 584-585; R. Kubicki, Zakony mendykanckie, s. 101.

18 W tym miejscu warto dodać, że informacje o poglądach Lutra przynosili powracający ze studiów w Rzeszy synowie bogatych mieszczan, w tym i bezpośrednio z Wittenbergi; S. Kościelak, Katolicy w protestanckim Gdańsku od drugiej potowy XVI do końca XVIII wieku, Gdańsk 2012, s. 34. Wieści nieśli prawdopodobnie także zakonnicy, utrzymujący kontakty z centrami swych prowincji, znajdującymi się w Rzeszy (augustianie-eremici, franciszkanie konwentualni i obserwanci). Brak informacji o kontaktach z Lutrem jego współbraci z klasztorów augustianów-eremitów w Prusach. Z jego nauczaniem, w czasie gdy należał jeszcze do wspólnoty mendykanckiej, mógł się zetknąć w Wittenberdze studiujący tam w 1510 r. franciszkanin gdański Aleksander Svenichen; Aus ungedruckten Franziskanerbriefen des XVI. Jahrhunderts, hrsg. L. Lemmens, Münster i. W. 1911, s. 59-60. Być może wykładów Lutra słuchał także gwardian klasztoru franciszkanów w Gdańsku Teofil Quant; ibidem, nr 2, s. 92, przyp. 4. 
formalnie zrzucić habit po 18 latach od wstąpienia do wspólnoty augustianów-eremitów ${ }^{19}$.

Wszystkie te wydarzenia i czynniki były sprzęgnięte z silną reakcją społeczną, której motywy miały też podłoże ekonomiczne. Rozruchy społeczne obok haseł dotyczących reformy życia kościelnego, w tym przede wszystkim dyscypliny kleru, kwestionowały też dotychczasowy system władz w miastach, żądając udziału pospólstwa w życiu politycznym gminy. Wydarzenia te dotyczyły również miast Prus Królewskich: Gdańska, Elblagga, Torunia, Braniewa oraz - znajdującego się w Prusach Zakonnych - Królewca. W Gdańsku przejawem dokonujących się zmian była odnotowana w 1522 r. działalność, piętnującego nadużycia w Kościele, kaznodziei Jacoba Heggego ${ }^{20}$ i zorganizowana w 1524 r. przez mieszczanina Hansa Pelkena parada, w trakcie której wprost kpiono z życie zakonnego i nawoływano do porzucania klasztoró $w^{21}$. Równolegle z tymi wydarzeniami uwidocznił się wyraźny kryzys wewnętrzny, w jakim znalazły się poszczególne klasztory mendykantów na tym terenie. Niestety nie znamy dokładnie jego stopnia ${ }^{22}$. Pewne wyobrażenie daje jednak zachowana do dziś korespondencja ${ }^{23}$. Kryzys panujący w poszczególnych klasztorach franciszkanów ujawnia już treść listów wymienianych pomiędzy braćmi w $1522 \mathrm{r}$. W piśmie z 3 lutego brat Marcin Leuthner z Braniewa informował kustosza Aleksandra Svenichena, że tamtejszy konwent opuścił zakrystianin Jakub, co tłumaczył wpływem nauk Lutra. Przy okazji wspominał

19 H.-M. Stamm, op. cit., passim; P. Chaunu, Czas reform. Historia religii i cywilizacji (1250-1550), tł. J. Grosfeld, Warszawa 1989, s. 341-343, 417, 425; E. L. Saak, op. cit.

20 J. Możdżeń, op. cit., s. 77-78.

${ }^{21}$ S. Kościelak, op. cit., s. 35, 38.

22 Przywoływany niekiedy w tym kontekście przypadek Jacoba Knadego (Knothego), rzekomo z miejscowego klasztoru dominikanów, który łamiąc śluby zakonne, wszedł w związek małżeński, a przy tym, jako kaznodzieja w kościele św. Piotr i Pawła, miał głosić już w 1518 r. poglądy krytykujące stan Kościoła, odwołując się do wystąpienia Lutra, miał w rzeczywistości miejsce w 1525 lub 1526 r.; zob. P. Simson, Wann hat der Danziger Priester Jakob Knothe geheiratet?, „Mitteilungen des Westpreussischen Geschichtsvereins”, 14, 1915, 1, s. 4. Inaczej, choć z wahaniem, S. Kościelak, op. cit., s. 34-35.

23 Kilka listów z tego okresu wydał P. Schmidt, Die St. Trinitatis=Kirche zu Danzig nach Vergangenheit und Gegenwart, Danzig 1901, s. 99-107; inne zob. Aus ungedruckten Franziskanerbriefen, nr 1-11, s. 90-109; Briefe und Urkunden des XVI. Jahrhunderts zur Geschichte der sächsischen Franziskaner, hrsg. L. Lemmens, „Beiträge zur Geschichte sächsischen Franziskanerprovinz”, 4/5, 1911/1912, s. 44-62. 
o najnowszych wieściach na temat sytuacji w Królewcu. Pewien przybysz z Wrocławia miał tam m.in. opowiadać, że klasztor franciszkanów w Wittenberdze został opuszczony przez zakonników i stoi zamknięty ${ }^{24}$. Komentując te wieści, Marcin pisał, że przyczyną porzucenia habitów przez licznych zakonników było to, że ludzie nie chcieli ich wspierać jałmużną. Opisał też sytuację w jego własnym konwencie w Braniewie. Jak to lapidarnie i zarazem dobitnie określił: „są tam liczni gwardianie i każdy chce rządzić po swojemu" (tł. R.K.) ${ }^{25}$. Opinia ta wymownie opisuje rozkład dyscypliny w klasztorze i nastroje panujące wśród zakonników ${ }^{26}$. Wydaje się, że w podobnym kierunku zmierzała wówczas sytuacja wewnętrzna w konwentach franciszkanów w Gdańsku i Toruniu. W liście z 13 października 1523 r. gwardian w Toruniu Franciszek Wynther pisał z przejęciem do przełożonego klasztoru w Gdańsku Teofila Quanta o ostatnich wypadkach w jego klasztorze $^{27} .8$ października do klasztoru w Toruniu przybył brat Krzysztof Medingen, który wystąpił otwarcie przeciw braciom, w tym i osobiście przeciw gdańskiemu gwardianowi i religii katolickiej. Braci nazwał faryzeuszami, podważał regułę i sam zakon. Następnie prowadził poufne narady z lektorem i wicegwardianem klasztoru. Franciszek Wynther w tej sytuacji zdecydował się 10 października opuścić klasztor, a o tym, co się tam działo poinformowali go później inni bracia. $\mathrm{Z}$ ich relacji wynikało, że Medingen powoływał się na osobę samego przełożonego kustodii pruskiej franciszkanów, który również miał mieć jakoby zamiar porzucenia życia zakonnego. Informację taką rozgłaszano w mieście, co spotkało się z dobrym przyjęciem. W tej sytuacji Franciszek prosił gwardiana w Gdańsku o przybycie do Torunia wraz z gwardianem z Braniewa, aby zaprzeczyć tym plotkom. Z relacji Franciszka wynika, że wraz z Medingenem miał działać w Toruniu jeszcze inny, bliżej nieznany, brat Maciej Feyster z Hogensteyn. Po tych zajściach sytuacja w jego konwencie była bardzo skomplikowana. Pisał, że nie może być pewny decyzji swych zakonników,

24 Aus ungedruckten Franziskanerbriefen, nr 2, s. 92.

25 „Et multi fratres relinquunt habitum propter hanc causam, quia homines nolunt eis subvenier suis elemosinis etc. In conventu Braunsbergensi que ibidem aguntur, eciam aliquid scribam. Sunt enim ibidem multi gwardiani, et unus quisque vult regere secundum caput suum", ibidem.

26 R. Kubicki, Zakony mendykanckie, s. 298.

27 Aus ungedruckten Franziskanerbriefen, nr 5, s. 97-99; USF II, nr 543, s. 141. Treść dokumentu przytoczył w uwspółcześnionej wersji językowej P. Schmidt, op. cit., s. 103-104. 
choć część z nich mówiła mu, że nie chce opuszczać klasztoru i radziła nawet odesłać wahających się do kustosza, gdyż oni nie chcą utrzymywać tych, którzy myślą o porzuceniu wspólnoty. Przy okazji Franciszek wspomniał też o sprawie młodego brata z konwentu w Gdańsku, Marcina Koenicka. Ten ostatni przekazał uprzednio socjuszowi Franciszka prywatny list do matki z prośbą o jego dostarczenie do Chełmna. Gdy socjusz poinformował o tym Franciszka, ten odebrał mu list, a po jego przeczytaniu odesłał w załączeniu do gwardiana w Gdańsku, aby ten poznał zamiary Koenicka. W liście tym dzielił się on z matką swym kompletnym zagubieniem. Pisał, że ma zamiar porzucić zakon („gancz aus der kappen”), sam już nie wie, kim jest, a duchowni w klasztorze są do niczego ${ }^{28}$. Prosił matkę o przyjazd do Gdańska, aby się z nią naradzić, co ma dalej robić. W tym czasie bardzo skomplikowana była również sytuacja w klasztorze dominikanów w Toruniu. Opuściło go już sześciu zakonników, a kolejny szykował się, by pójść w ich ślady ${ }^{29}$.

Przytoczone w liście gwardiana toruńskiego Franciszka Wynthera informacje o wydarzeniach $\mathrm{w}$ jego klasztorze i postawie zajmowanej przez innych zakonników były oczywiście pośrednio skutkiem szerszych zmian, jakie dokonywały się w tym czasie w życiu miasta, w których coraz większego znaczenia nabierali zwolennicy radykalnych rozwiązań. Przypomnijmy, że postulaty reformy życia kościelnego związane były z wystąpieniami pospólstwa. W Toruniu wybuch niezadowolenia wobec dotychczasowego porządku społecznego nastąpił, gdy rada miasta przystąpiła do poboru podatku na rzecz króla, uchwalonego na zjeździe stanów pruskich w Grudziądzu ${ }^{30}$. Niepokoje rozpoczęły się 10 marca 1523 r., a pośród żądań pospólstwa znalazły się także te dotyczące zaprowadzenia dyscypliny wśród kleru. Postulowano m.in. zaprzestanie przez księży i zakonników praktyk polegających na nakłanianiu starych ludzi do sporządzania legatów

28 „Ich wil gancz aus der kappen. Ich weiss nicht vor an dass ich byn; unser gestlikeith isth vor wor nichts", USF II, nr 542, s. 140; P. Schmidt, op. cit., s. 105 ; K. Kantak, op. cit., s. 365.

29 Aus ungedruckten Franziskanerbriefen, nr 5, s. 98; M. Biskup, Historia Torunia, t. 2, cz. 1: U schytku średniowiecza i w poczatkach odrodzenia (1454-1548), Toruń 1992, s. 216; Ł. Myszka, Dominikanie w Toruniu od XVI do XIX wieku. Katolicki zakon w protestanckim mieście, Kraków 2015 (Studia i Źródła Dominikańskiego Instytutu Historycznego w Krakowie, t. 15), s. 53-54; R. Kubicki, Zakony mendykanckie, s. 186, 299.

30 M. Biskup, Historia Torunia, t. 2, cz. 1, s. 147. 
testamentowych na rzecz osób duchownych ${ }^{31}$. Przywódcy pospólstwa formułowali także kolejne żądania, które 11 maja zostały wręczone radzie. Część z nich dotyczyła także spraw kościelnych, w tym przestrzegania praktyk religijnych i właściwego wypełniania swych obowiązków przez duchownych ${ }^{32}$. W odpowiedzi na te wydarzenia król wydał 22 sierpnia 1523 r. w Krakowie 55 artykułów znanych jako Reformatio Sigismundi ${ }^{33}$. Wśród nich uwzględniono także te, które były realizacją postulatu pospólstwa dotyczącego zakazu obecności duchownych przy spisywaniu testamentów ${ }^{34}$. Tekst Reformatio, zabraniający sporządzania zapisów testamentowych na rzecz duchowieństwa zakonnego, znalazł swe odbicie w treści nowego wilkierza miejskiego, opublikowanego 27 stycznia 1524 r. ${ }^{35}$ Decyzje króla nie uspokoiły jednak sytuacji. W 1525 r. przeciw zakonnikom wystąpił otwarcie zwolennik poglądów Lutra, mieszczanin Maciej Monsterberg. Choć rada miasta zabroniła mu dalszej działalności, to nie odniosła się do głoszonych przez niego poglądów. W tej sytuacji kryzys wewnątrz klasztorów postępował. Zakonnicy opuszczali wspólnotę, zabierając samowolnie wyposażenia klasztorne, czemu próbowały przeciwdziałać władze zakonne i biskup chełmiński Jan Konopacki. Ostatecznie wydał on zgodę na przechowywanie tegoż wyposażenia przez władze miejskie ${ }^{36}$. W tym czasie w złej sytuacji materialnej znajdował się również klasztor franciszkanów w Chełmnie. W 1523 r. jego gwardian prosił współbraci z Gdańsku o przysłanie mu żywności ${ }^{37}$.

Równolegle $\mathrm{z}$ wydarzeniami $\mathrm{w}$ Toruniu następowała radykalna zmiana sytuacji w znajdującym się wciąż pod władzą wielkiego mistrza zakonu krzyżackiego Królewcu. W przypadku tamtejszych

31 J. Buława, Walki spoteczno-ustrojowe w Toruniu w I potowie XVI wieku, Toruń 1971, s. 44-47. Artykuły dotyczące działalności zakonów mendykanckich to: art. 17: „Tylko za specjalną wiedzą i zezwoleniem rady osoby duchowne i zakonnice mogą udawać się do chorych starców. Zakaz wydaje się w tym celu, by osoby duchowne nie nakłaniały swych podopiecznych do zapisów testamentowych na rzecz duchownych lub instytucji kościelnych”, art. 38: „Zabrania się zapisywać działki miejskie duchowieństwu bądź osobom mającym śluby zakonne oraz obciążać te działki czynszem na korzyść osób duchownych. Czyni się to dla ułatwienia odbudowy zniszczonych domów".

32 Treść ich drukuje J. Buława, op. cit., s. 51-52.

33 Ibidem, s. 72-85.

34 Ibidem, s. 83-84.

35 T. Maciejewski, Wilkierze miasta Torunia, Toruń 1997, s. 72.

36 M. Biskup, Historia Torunia, t. 2, cz. 1, s. 217; Ł. Myszka, op. cit., s. 54; R. Kubicki, Zakony mendykanckie, s. 296.

37 USF II, nr 556, s. 143; R. Kubicki, Zakony mendykanckie, s. 304. 
franciszkanów obserwantów decydujące wydarzenia rozegrały się w czasie Wielkanocy roku 1524, gdy rozemocjonowane pospólstwo usunęło ich z klasztoru ${ }^{38}$. Wydarzenia te były pośrednio skutkiem postawy zajmowanej przez regenta w Prusach, biskupa sambijskiego Georga von Polentza, który otwarcie sprzyjał zwolennikom Lutra ${ }^{39}$.

Wydarzenia w Królewcu oczywiście odbiły się szerokim echem wśród innych wspólnot mendykanckich, nie tylko franciszkańskich. Pośród tych ostatnich w szczególnie skomplikowanej sytuacji znajdował się w tym czasie ich klasztor w Braniewie ${ }^{40}$. Miasto, formalnie należące do biskupów warmińskich, w czasie konfliktu polsko-krzyżackiego (1519-1521) znalazło się pod kontrolą namiestnika krzyżackiego Piotra von Dohna, co utrudniało biskupowi reakcję na wystąpienia zwolenników reformacji. Zdając sobie sprawę ze skomplikowanej sytuacji panującej w mieście, w liście do jego mieszkańców z około 3 kwietnia 1524 r. nowy biskup warmiński Maurycy Ferber ostrzegał przed wystąpieniami zwolenników nowej doktryny oraz atakami na duchownych i zakonników ${ }^{41}$. W tym czasie miejscowi franciszkanie obawiali się prób odebrania im wyposażenia kościoła ${ }^{42}$. Zamiar taki rzeczywiście istniał, o czym świadczy list rady miasta skierowany 19 maja 1524 r. do regenta Prus, biskupa von Polentza, w którym prosiła ona o odłożenie momentu odebrania srebrnego wyposażenia fary i klasztoru Franciszkanów do czasu przybycia do Prus wielkiego mistrza ${ }^{43}$. Podobnie skomplikowana była sytuacja klasztorów w Gdańsku, gdzie intensywnie rozwijała się w tym czasie działalność kaznodziejów propagujących naukę Lutra $^{44}$. W tej sytuacji, w poczuciu zagrożenia, miejscowi dominikanie prosili o pomoc i interwencję u króla. W piśmie z 9 sierpnia

38 USF I, nr 289, s. 67; F. Gause, Die Geschichte der Stadt Königsberg in Preussen, Bd. 1, Köln-Graz 1965, s. 213.

39 L. Lemmens, Die Franziskanerkustodie Livland und Preussen. Beitrag zur Kirchengeschichte der Gebiete des Deutschen Ordens, Düsseldorf 1912, s. 40-41; USF I, nr 278-280, 284-285; R. Kubicki, Zakony mendykanckie, s. 316-317.

40 Rozwój sytuacji w Braniewie omówił w szerszym kontekście H. Zins, Początki reformacji na Warmii, w: idem, W kregu Mikotaja Kopernika, Lublin 1966, s. $124-142$.

41 USF II, nr 546, s. 141; J. Kolberg, Ermland im Kriege des Jahres 1520, „Zeitschrift für die Geschichte und Altertumskunde Ermlands”, 15, 1905, s. 553-554; R. Kubicki, Zakony mendykanckie, s. 305.

42 USF II, nr 547, s. 142; K. Kantak, op. cit., s. 365-366.

43 USF II, nr 551, s. 142.

44 S. Kościelak, op. cit., s. 35-38. 
1524 r. prowincjał Andrzej z Parczowa donosił królowi, że dominikanom w mieście zagrażają zwolennicy Lutra ${ }^{45}$. O prawdziwości tych doniesień świadczą wydarzenia, które rozegrały się później w Gdańsku. Protagoniści nauk Lutra, odwołując się do radykalnych środowisk w mieście, doprowadzili do odsunięcia od władzy dotychczasowej rady miejskiej, powołując w jej miejsce własnych przedstawicieli, 12 rentmistrzów i jako hauptmana Jana Wendlanda ${ }^{46}$. Jedną z decyzji podjętych przez rentmistrzów było odebranie klasztorom cennego wyposażenia i umieszczenie go $\mathrm{w}$ ratuszu ${ }^{47}$. Wkrótce też zawezwano zakonników do odbycia publicznej dysputy, głosząc zarazem otwarcie postulat likwidacji klasztorów w mieście ${ }^{48}$. Dominikanom i franciszkanom nakazano opuścić klasztory, a jeśli chcieli nadal pozostać w mieście, to musieli przenieść się do klasztoru Karmelitów ${ }^{49}$. Regulacje te miały nie dotyczyć tylko braci starych i chorych, którzy pod strażą mogli pozostać w swych konwentach ${ }^{50}$. Opuszczone w ten sposób obiekty zmieniono na szpital (klasztor dominikański) i „szkołę grecką" (budynki należące do franciszkanów) ${ }^{51}$. Postanowienia te wkrótce wprowadzono w życie. Świadczy o tym treść listu napisanego

45 R. Kubicki, Środowisko dominikanów, s. 40; idem, Zakony mendykanckie, s. 291.

46 M. Bogucka, Przemiany spoteczne i walki spoteczno-polityczne, w: Historia Gdanska, t. 2, red. E. Cieślak, Gdańsk 1982, s. 234; S. Kościelak, op. cit., s. 39.

47 S. Kościelak, op. cit., s. 39.

48 Dokładny opis postanowień zob. Aus ungedruckten Franziskanerbriefen, s. 65; P. Simson, Geschichte der Stadt Danzig, Bd. 2, Danzig 1918, s. 68; R. Kubicki, Franciszkanie w Gdańsku - zaplecze spoteczne klasztoru oraz jego zwiazki z miastem w XV i pierwszej potowie XVI w., „Nasza Przeszłość”, 115-116, 2011, s. 175.

49 USF II, nr 561, s. 145.

50 P. Simson, Geschichte, Bd. 2, s. 71-72.

51 „Das grawe monnichen kloster machete sy zcu eyner Grekischen schulen”, Bernt Stegmann's Chronik vom Aufruhr 1525, w: Scriptores rerum Prussicarum, Bd. 5, hrsg. Th. Hirsch, s. 561; USF II, nr 561-562, s. 145. O rzeczywistej zamianie klasztoru dominikanów na szpital i odwiedzaniu przebywających w konwencie karmelitów współbraci wspominał w swej kronice Szymon Grunau; zob. S. Zonenberg, Kronika Szymona Grunaua, Bydgoszcz 2009, s. 32 . Uwagi nt. postrzegania zwolenników reformacji przez Grunaua przedstawił S. Zonenberg, Wizerunek heretyka w "Preußische Chronik” dominikanina Szymona Grunaua, w: Persona, gestus habitusque insygnium. Zachowania $i$ atrybuty jako wyznaczniki tożsamości spotecznej $w$ średniowieczu, red. J. Banaszkiewicz, J. Maciejewski, J. Sobiesiak, Lublin 2009, s. 103-116. Na temat wizji reformacji przedstawionej przez Grunaua zob. J. Możdżeń, Die Vision der fortschreitenden Reformation in Preußen aus der Sicht des Dominikaners Simon Grunau $\left({ }^{*} 1455-1465 / 1470\right.$ $-+1529 / 1530)$, „Biuletyn Polskiej Misji Historycznej. Bulletin der Polnischen Historischen Mission”, 7, 2012, s. 361-387. 
29 stycznia 1525 r. przez przeora dominikańskiego Arnolda Galliego (w dokumencie określił się jako dawny przeor) oraz jego współbrata Piotra Bischofa. Prosili oni nowego burmistrza Jerzego Zimmermanna ${ }^{52}$, aby zgodnie z zapewnieniem danym im przez Konrada von Suchtena otrzymywali z miasta żywność potrzebną do codziennego utrzymania oraz by pozwolono im na zabranie z klasztoru pozostałych tam książek i naczyń liturgicznych ${ }^{53}$. Nie znamy odpowiedzi adresata na ten list. W tym czasie nie było też reakcji króla, który zajęty był do kwietnia negocjacjami z wielkim mistrzem Albrechtem, zakończonymi ostatecznie zawarciem 9 kwietnia układu krakowskiego.

W związku z tym nie było też początkowo reakcji dworu na wydarzenia, które miały miejsce w Elblągu. Również tam pospólstwo wystąpiło przeciwko zakonnikom ${ }^{54}$. Wypadki nastąpiły po tym, gdy rada miasta 1 lutego 1525 r. zakazała dominikanom używania w nocy dzwonu klasztornego oraz głoszenia kazań w kościele. W tej sytuacji przeor i lektor opuścili potajemnie klasztor, próbując ratować jego cenne wyposażenie. Wprawdzie zostali doścignięci przez wysłanników rady we wsi Krzyżewo pod Malborkiem, nie ujęto ich jednak, gdyż teren ten był już poza jurysdykcją miasta ${ }^{55}$. W związku z tym rada zarządziła konfiskatę pozostałego wyposażenia kościoła, w tym i naczyń liturgicznych. Warto dodać, że w tym czasie z Gdańska przybył do Elbląga dawny karmelita Maciej (Mathias), względnie Mateusz Bienwald (Bernwalt) ${ }^{56}$, który propagował doktrynę Lutra ${ }^{57}$. Jego działalność miała zapewne duży wpływ na sytuację miejscowych zakonników. Pewne zmiany w sytuacji politycznej w mieście nastąpiły w listopadzie $1525 \mathrm{r}$. Na skutek interwencji króla swe stanowiska odzyskali wówczas dawni członkowie rady.

Podobnie było w przypadku wydarzeń rozgrywających się w Gdańsku. Jeszcze 8 maja 1525 r. król wzywał mieszkańców do przywrócenia

52 Jerzy Zimmermann, pisarz miejski, burmistrz w 1525 r., w 1526 r. zwolniony z funkcji; zob. J. Zdrenka, Urzędnicy miejscy Gdańska w latach 1342-1792 i 1807-1814. Biogramy, Gdańsk 2008, s. 387-388.

53 APGd, Akta miasta Gdańska, Dokumenty i listy do 1525 r., 300, D/46, nr 64.

54 H. Zins, Rewolta w Elblagu w 1525 r., w: idem, W kregu Mikotaja Kopernika, s. 146-203; M. Pawlak, Reformacja i kontrreformacja. Kościoty i wyznania, w: Historia Elblaga, t. 2, cz. 1, red. A. Groth, Gdansk 1996, s. 173-181; R. Kubicki, Zakony mendykanckie, s. 294.

55 E. Carstenn, Geschichte der Hansestadt Elbing, Elbing 1937, s. 309; H. Zins, Rewolta $w$ Elblagu $w 1525$ r., s. 170-171; M. Pawlak, op. cit., s. 176.

56 S. Kościelak, op. cit., s. 36.

57 E. Carstenn, op. cit., s. 309; H. Zins, Rewolta w Elblagu w 1525 r., s. 170. 
dawnego porządku w mieście. Ostatecznie w grudniu tego roku zapadła decyzja o podporządkowaniu się żądaniom króla ${ }^{58}$. Do ich realizacji droga była jednak wciąż daleka. Nie inaczej wyglądała sytuacja w innych miastach. W Braniewie jeszcze 24 lutego 1526 r. rada miasta zakazała franciszkanom głoszenia kazań, o czym informowali oni biskupa warmińskiego Maurycego Ferbera w swym liście z 10 marca $^{59}$. W Gdańsku sytuację zmieniło dopiero osobiste przybycie króla 17 kwietnia 1526 r. Jednym z wydanych wówczas postanowień był nakaz zwrotu zakonnikom ich klasztorów ${ }^{60}$. Dominikanie powrócili do swojej siedziby 16 maja $^{61}$. Wystąpienie pospólstwa uznane zostało za bunt, a jego przywódców ścięto. 20 lipca król głosił tzw. Statuta Sigismundi, które stały się podstawą ustroju miejskiego. Określono w nich m.in. sposób dalszego zarządzania drogocennym wyposażeniem klasztorów, w tym i udostępnianymi jedynie w czasie świąt paramentami ze złota i srebra ${ }^{62}$. Podobne rozstrzygnięcia dotyczyły także sytuacji klasztorów w Elblągu i Braniewie. Do Elbląga komisarze królewscy przybyli w lipcu 1526 r. Zgodnie $\mathrm{z}$ wydanymi 13 sierpnia statutami królewskimi przeora i starszych klasztoru dopuszczono do skrzyni ze srebrami, przekazując im jeden z kluczy. Zwrócono im też naczynia liturgiczne używane podczas sprawowania codziennych nabożeństw ${ }^{63}$. Zarządzenia nakazywały również, aby zwolennicy nauki Lutra opuścili miasto w ciągu 2 tygodni (art. 1), tylko jeden dzień na wyjazd dano zaś księżom, zakonnikom i zakonnicom, którzy wstąpili w związki małżeńskie lub w inny sposób naruszyli przepisy kościelne (art. 2) ${ }^{64}$. Decyzje króla miały też wpływ na sytuację w Braniewie. Jeszcze latem 1526 r. król

58 M. Bogucka, op. cit., s. 244; R. Kubicki, Zakony mendykanckie, s. 293.

59 USF II, nr 565, s. 146.

60 P. Schmidt, op. cit., s. 14; Aus ungedruckten Franziskanerbriefen, s. 68-69.

61 P. Simson, Geschichte, Bd. 2, s. 92.

62 Postanowiono w nich m.in., że rada będzie wyznaczyła spośród mieszczan po dwóch przykładnych obywateli (duos probos cives), którzy będą nadzorować spisanie złotego i srebrnego wyposażenia każdego z klasztorów w mieście. Miało być ono przechowywane w zamykanej na dwa klucze skrzyni, które po jednym będą mieli przedstawiciele miasta i przełożeni klasztoru, a cenne paramenty będą udostępniane na potrzeby sprawowania kultu jedynie w czasie świąt; P. Simson, Geschichte, Bd. 4, nr 153, s. 146. W innym miejscu P. Simson nieprecyzyjnie podał, że dotyczyło to również nadzoru nad majątkiem klasztornym; ibidem, Bd. 2, s. 95; za nim informację tę powtarza S. Kościelak, op. cit., s. 43.

63 R. Kubicki, Środowisko dominikanów, s. 42.

${ }^{64}$ H. Zins, Rewolta w Elblagu w 1525 r., s. 195. 
skierował do władz miejskich i mieszczan Braniewa list w obronie zakonników $^{65}$. Przybyli do miasta komisarze królewscy 28 sierpnia wydali zaś dokument przywracający religię katolicką w mieście i wprowadzający surowe kary dla osób odpowiedzialnych za rabunki kościołów i klasztoru ${ }^{66}$. Obok zarządzeń królewskich wkrótce nastąpiła też reakcja miejscowych biskupów. 11 maja i 4 sierpnia 1526 r. biskup warmiński Maurycy Ferber wydał w Elblągu dwa dokumenty, wymieniając w nich imiennie księży i zakonników, którzy przeszli na luteranizm, w pierwszym nakazując opuszczenie Elbląga i terenu diecezji warmińskiej, a w drugim przybycie do Elblagga i stawienie się przed obliczem biskupa ${ }^{67}$. Wśród nich było aż 15 dominikanów z Elbląga, jeden karmelita z Gdańska i dwóch franciszkanów z Nowego nad Wisłą, którzy porzucili uprzednio swoje wspólnoty. Ponadto w obu dokumentach wspomniano jeszcze księży diecezjalnych, w pierwszym 6, a w drugim 11, w tym 5 wymienionych już w pierwszym dokumencie ${ }^{68}$. Podobne kroki podjął w Gdańsku biskup włocławski Maciej Drzewicki. Wydał on 12 lipca 1526 r. w mieście dokument, w którym nakazywał opuszczenie terenu Gdańska i diecezji włocławskiej przez łącznie 100 zakonników i księży oraz 20 sióstr podejrzewanych o sprzyjanie luteranizmowi. Wśród nich wymieniono 19 franciszkanów, pochodzących prawdopodobnie z różnych klasztorów całej prowincji, 19 karmelitów z Gdańska, w tym i byłego przeora klasztoru Augustyna Ceriariego ${ }^{69}$ i 10 sióstr karmelitańskich ${ }^{70}$. Na podstawie

65 USF II, nr 568, s. 147; Acta Tomiciana. Tomus octavus decimus epistolarum, legationum, responsorum, actionum et rerum gestarum. Serenissimi Principis Sigismundi Primi Regis Polonie et Magni Ducis Lithuanie, t. 8, wyd. A. T. Działyński, L. Koenig, Poznań 1876, nr 85, s. 110-111; K. Kantak, op. cit., s. 366; R. Kubicki, Zakony mendykanckie, s. 294.

66 USF II, nr 570, s. 147; Acta Tomiciana, t. 8, nr 90, s. 114-119.

67 Rywalizacja katolików z luteranami, nr 2, 6, s. 35-37, 39-40; R. Kubicki, Zakony mendykanckie, s. 295.

68 Rywalizacja katolików z luteranami, nr 6, s. 39-40.

69 Wybrany przeorem klasztoru w 1521 r. Dodajmy, że w 1524 r. kapituła wybrała nieznanego z imienia przeora klasztoru; Archiwum Generalne OO. Karmelitów w Rzymie, II Polonia, Commune 1, Marcin Behm, Compendium libri Provinciae, 1677 r., s. 22.

70 Ogólne omówienie treści dokumentu zob. P. Schmidt, Pater Dr. Alexander, ein Nachtrag zur Geschichte der Danziger Trinitatiskirche, "Zeitschrift des Westpreussischen Geschichtsvereins", 44, 1902, s. 224; Aus ungedruckten Franziskanerbriefen, s. 68; USF II, nr 567, s. 146; R. Kubicki, Zakony mendykanckie, s. 299-300. Lista księży, zakonników i zakonnic została zamieszczona w aneksie do niniejszego artykułu. 
przywołanych dokumentów biskupów można stwierdzić, że w diecezji warmińskiej o sprzyjanie nowej wierze oskarżono łącznie 11 księży diecezjalnych i 18 zakonników, a we włocławskiej - 40 księży diecezjalnych i 60 zakonników. Przy czym w dokumencie biskupa włocławskiego zaznaczono, że spośród 100 wymienionych księży, kapłanów i braci łącznie 16 księży diecezjalnych i 6 zakonników zawarło związki małżeńskie ${ }^{71}$. Co ciekawe, nie wymieniono w nim natomiast dominikanów ani augustianów-eremitów. W przypadku tych ostatnich jest to o tyle zrozumiałe, że na terenie działania biskupstwa włocławskiego na Pomorzu Gdańskim nie mieli oni żadnego klasztoru, ponieważ miasto Chojnice i tamtejsza placówka zakonna wchodziły w skład obszaru podlegającego arcybiskupom gnieźnieńskim.

Skutki pierwszych wystąpień zwolenników reformacji do 1526 r.

Dzięki interwencji królewskiej zakonnicy odzyskali w drugiej połowie 1526 r. swe klasztory. Nie oznaczało to jednak przywrócenia normalnych warunków ich funkcjonowania. Zbyt duże zmiany nastąpiły w międzyczasie w zapleczu społecznym poszczególnych konwentów, a także w ich składzie osobowym. Przykładowo w Gdańsku rada miasta popierała nadal umiarkowanego kaznodzieję, który pozostał w klasztorze franciszkanów, Aleksandra Svenichena. Stan ten nie trwał jednak długo, gdyż zmarł on już 1529 r., w trakcie epidemii, jaka nawiedziła wówczas miasto ${ }^{72}$. O kryzysie życia zakonnego świadczą

71 Liczbę 76 księży, zakonników i sióstr z Gdańska, którzy mieli w tym czasie zawrzeć związki małżeńskie, podawał Szymon Grunau; zob. S. Grunau’s preussische Chronik, Bd. 1, hrsg. M. Perlbach, Leipzig 1876, s. 438; J. Możdżeń, The Beginnings, s. 82.

72 Aleksander Svenichen był różnie oceniany. Część badaczy widziała w nim prekursora reformacji w mieście; zob. H. Freytag, Die Beziehungen Danzigs zu Wittenberg in der Zeit der Reformation, „Zeitschrift des Westpreussischen Geschichtsvereins", 38, 1898, s. 20, 26, 29-32, 49, 50. Zdaniem innych był on wierny swemu zakonowi i dążył do dokonania niezbędnych reform w ramach Kościoła, odrzucając naukę Lutra; zob. Aus ungedruckten Franziskanerbriefen, s. 56-69; na jego temat zob. też P. Schmidt, Pater Dr. Alexander, s. 224; K. Kantak, op. cit., s. 366; Z. Nowak, Svenichen Aleksander, w: Stownik biograficzny Pomorza Nadwiślańskiego, t. 4, red. Z. Nowak, Gdańsk 1997, s. 301-302; S. Kościelak, op. cit., s. 44; T. Borawska, Svenichen (Schweinichen) Aleksander (ok. 1480-1529), franciszkanin, kustosz pruski, kaznodzieja gdański, PSB, 46, 2009, s. 114-115; T. Borawska, H. Rietz, Aleksander Svenichen (zm. 1529 r.) - franciszkanin z Prus zagubiony $w$ zamęcie reformacji, w: Mikotaj Kopernik i jego świat. Środowisko, przyjaciele, echa wielkiego odkrycia, Torun 2014, s. 207-221. 
natomiast wzmianki o licznych zakonnikach i braciach laikach, którzy opuścili wspólnotę już w pierwszym okresie rozwoju reformacji $\mathrm{w}$ mieście. Wielu z nich zawarło związki małżeńskie, w tym m.in. Paweł Quanth, być może krewny gwardiana franciszkanów Teofila Quanta (1510-1512, 1519-1526) ${ }^{73}$. Charakterystyczne jest, że za trwaniem w życiu zakonnym opowiedzieli się zazwyczaj przedstawiciele starszego pokolenia zakonników, przełożeni klasztorów (przeorzy, gwardianie), jak o tym świadczą przywołane listy przeora dominikanów i gwardiana franciszkanów w Gdańsku, skierowane do przywódców wystąpień ludowych. Z ich treści wynika jednoznacznie, że starsi zakonnicy chcieli w spokoju dożyć swych dni w klasztorach. Po wydarzeniach z 1525 r. w klasztorze dominikanów w Gdańsku swą wysoką pozycję zachował Piotr Episcopi (Bischof), który w 1528 r. został nawet wikariuszem całej kontraty pruskiej ${ }^{74}$. Z kolei u dominikanów w Elblągu pozostało zapewne kilku zakonników, w tym i bracia ze średniego pokolenia. Spośród nich najdłużej żyli w konwencie wzmiankowani w 1514 i 1542 r. brat Walenty Schubarth i Bartłomiej Hedenreych, który pełnił jako ostatni funkcję przeora klasztoru do jego likwidacji ${ }^{75}$.

Ogromne problemy kadrowe dotyczyły wspólnoty karmelitów w Gdańsku. Opuściło ją bardzo wielu zakonników (20 osób), w tym i urzędujący od 1521 r. przeor. Kryzys dotknął także wspólnotę żeńską karmelitanek, którą porzuciło 10 osób. Co więcej, prawie od początku jednym z aktywnych kaznodziejów popierających reformację w Gdańsku i Elblągu był wywodzący się z ich klasztoru Maciej (Mathias), względnie Mateusz Bienwald (Bernwalt). Jeszcze w sierpniu $1524 \mathrm{r}$. został on ustanowiony przez pospólstwo kaznodzieją w kościele św. Bartłomieja ${ }^{76}$. Przy czym w okresie władzy pospólstwa w mieście klasztor Karmelitów nie został im odebrany, stając się zbiorczym domem dla wszystkich pozostałych w mieście zakonników.

73 Ma na to wskazywać spis braci kapłanów (registrum fratrum ecclesiasticorum) i laików (fratrum laicorum oder leyenbrüder) kościoła św. św. Piotra i Pawła. Mieli oni uprzednio w części porzucić klasztor franciszkanów. Zestawienie oparto na odpisie najstarszej księgi witryków kościoła św. św. Piotra i Pawła, prowadzonej w latach 1514-1522, wykonanym w 1805 r. Fragmenty tej księgi opublikował P. Schmidt, Die Gedenkbücher der Danziger Trinitatiskirche, „Mitteilungen des Westpreussischen Geschichtsvereins”, 5, 1906, 4, s. 72-74.

74 R. Kubicki, Środowisko dominikanów, s. 184-185.

75 Ibidem, s. 154, 191.

76 S. Kościelak, op. cit., s. 39; R. Kubicki, Zakony mendykanckie, s. 308. 
W drugiej połowie 1526 r., gdy nastąpiła restauracja dawnego porządku, karmelici mogli znów oficjalnie prowadzić swą działalność duszpasterską. Nie było to jednak łatwe w sytuacji, gdy klasztor opustoszał, a opowiadającego się po stronie zwolenników reformacji wspomnianego już Bienwalda (Bernwalta) biskup warmiński Maurycy Ferber wzywał do stawienia się w celu złożenia wyjaśnieńn ${ }^{77}$. Daleka od stabilizacji była też sytuacja franciszkanów w Braniewie. Zauważalny był upadek życia wewnętrznego w klasztorze. Podobnie jak w Gdańsku, porzucali go wciąż kolejni bracia, problemem byli też wahający się zakonnicy, jak brat Franciszek Radike, który opuścił klasztor, ale nie zdecydował się na jednoznaczne opowiedzenie się po stronie reformacji. Wprawdzie popadł on w konflikt $\mathrm{z}$ własnymi współbraćmi w klasztorze, ale zdaniem ówczesnego kanonika warmińskiego Tiedemanna Giesego istniała szansa, że mógłby on być pożyteczny dla Kościoła także jako człowiek świecki, gdyby właściwie spożytkować jego talent w głoszeniu Słowa Bożego. Warunkiem było jednak udzielenie mu wsparcia i odsunięcie od środowiska, w którym wówczas funkcjonował, o czym Giese pisał w liście do biskupa warmińskiego Maurycego Ferbera 24 sierpnia 1534 r., prosząc o osobiste wysłuchanie Franciszka i pomoc w powrocie na właściwą drogę ${ }^{78}$. Dodajmy, że sytuacja franciszkanów w Braniewie była bardzo skomplikowana. Mimo że przez pewien czas mogli oni jeszcze liczyć na pewne wsparcie ze strony mieszczaństwa, nie zahamowało to jednak dalszego wyludniania się konwentu ${ }^{79}$. W przypadku franciszkanów poważnym problemem był też faktyczny upadek ich prowincji zakonnej. Wystarczy wspomnieć, że do 1530 r. zakonnicy opuścili około 30 klasztorów, do $1540 \mathrm{r}$. kolejne 40, a do $1554 \mathrm{r}$. łącznie około 90 należących do prowincji saskiej św. Jana (franciszkanów konwentualnych) ${ }^{80}$.

Podobnie wyglądała sytuacja w saskiej kongregacji zreformowanych klasztorów augustianów-eremitów. Po ustąpieniu jej wikariusza generalnego Jana von Staupitza nowo wybrany wikariusz Wenzeslaus Link, który był przeorem Lutra w Wittenberdze i otwarcie popierał

77 Rywalizacja katolików z luteranami, nr 2, s. 35-36; nr 6, s. 39-40.

78 USF II, nr 581, s. 150; T. Borawska, Życie umystowe na Warmii $w$ czasach Mikotaja Kopernika, Toruń 1996, s. 135-136; R. Kubicki, Zakony mendykanckie, s. 306.

79 USF II, nr 600, s. 159; nr 619, s. 163.

80 Obliczenia oparto na zestawieniach zawartych w Spuren franziskanischer Geschichte, s. 259-303; R. Kubicki, Zakony mendykanckie, s. 300. 
reformację, podjął decyzję o przekształceniu klasztorów w dobrowolne wspólnoty życia ewangelicznego, co zostało zatwierdzone przez kapituły kongregacji odbyte w Wittenberdze i Grimmie. Skutkiem tego był szybki rozpad struktur zakonu na tych terenach i opustoszenie wielu klasztorów ${ }^{81}$. W związku z tym w bardzo trudnej sytuacji znalazły się również cztery konwenty augustianów-eremitów działające w Prusach Krzyżackich i Królewskich. Do 1526 r. przestała właściwie istnieć prowincja saska zakonu, a pozostałe, nieliczne klasztory, które przetrwały, podporządkowano kongregacji lombardzkiej zgromadzenia ${ }^{82}$. W jeszcze trudniejszym położeniu znaleźli się w państwie krzyżackim franciszkanie obserwanci. Jak już wspomniano, z konwentu $\mathrm{w}$ Królewcu zakonnicy zostali wypędzeni przez wzburzony tłum w czasie Wielkanocy $1524 \mathrm{r}$. i nigdy tam już nie powrócili ${ }^{83}$. Opustoszały również ich pozostałe domy w Zalewie i Tylży ${ }^{84}$.

Podsumowując, można stwierdzić, że kryzys, który dotknął klasztory mendykanckie już w pierwszych latach rozwoju ruchu reformacyjnego, wpłynął w zasadniczy sposób na ich dalsze losy. Jeśli nie doprowadził wprost do wyludnienia i opuszczenia, to bardzo osłabił je wewnętrznie, pozbawiając wielu, zazwyczaj młodych braci, którzy nie tylko opuścili wspólnotę, ale wręcz opowiedzieli się po stronie zwolenników reformacji i sami byli aktywnymi propagatorami nauk Lutra. Sytuację miejscowych konwentów pogarszał dodatkowo upadek rodzimych prowincji zakonnych w Rzeszy (franciszkanów obserwantów i augustianów-eremitów) ${ }^{85}$. W dłuższej perspektywie najważniejsze były jednak przemiany społeczne. Klasztory utraciły naturalne zaplecze $\mathrm{w}$ postaci ludności miast, która przeważnie przyjęła nowe wyznanie i do życia klasztornego odnosiła się jeśli nie z niechęcią, to $\mathrm{w}$ najlepszym razie $\mathrm{z}$ obojętnością. W tych warunkach przetrwały

81 Na terenie Rzeszy liczba klasztorów z 112 około 1500 r. spadła do 52 około 1555 r.; zob. M. K. Wernicke, Die Augustiner-Eremiten, w: Orden und Klöster im Zeitalter von Reformation und katholischer Reform 1500-1570, Bd. 2, hrsg. F. Jürgensmeier, R. E. Schwerdtfeger, Münster 2006, s. 49-54, 60-64; R. Kubicki, Zakony mendykanckie, s. 310.

82 A. Poschmann, op. cit., s. 117; nt. stanu konwentów dawnej prowincji saskiej w połowie XVI w. syntetyczne zestawienie dał A. Kunzelmann, op. cit., s. 516-518. Z 36 klasztorów, które przyjęły reformę i przystąpiły do kongregacji zreformowanych domów w obrębie prowincji saskiej, opustoszały 23, a więc ponad 2/3; zob. ibidem, s. 516.

83 USF I, nr 289, s. 67; F. Gause, op. cit., s. 213.

84 R. Kubicki, Zakony mendykanckie, s. 315, 317.

85 Ibidem, s. 320. 
tylko te klasztory, które zyskały wsparcie dworu królewskiego (dominikanie i karmelici w Gdańsku), a w późniejszym czasie oparły się na szlachcie pomorskiej, która w większości pozostała przy katolicyzmie.

\section{Aneks}

Księża, zakonnicy i zakonnice ${ }^{86}$, którzy porzucili klasztory w Gdańsku i w diecezji włocławskiej, wymienieni w dokumencie biskupa włocławskiego Macieja Drzewickiego, wystawionym w Gdańsku 12 lipca 1526 r.; Archiwum Państwowe w Gdańsku, Akta miasta Gdańska, Dokumenty i listy po 1525 r., 300, 53/254, s. 5-7

s. 5 [...] Petrus Fexberk, Jacobus Heleke relapsus, Erhardus, Georgius Cepusiensis ungarus, Joannes Beyer, Pancracius, Joannes Lancgknecht, Michael Galliniculus alias Urhan, Bernardus Clementis prior Pepliniensis, Joannes Grunewelcht, Petrus Puczenyk, Joannes Rosth relapsus, Laurencius organista Sancti Petri, Joannes Bonholz, Georgius de Toronia predicator ad Sanctam Barbaram, Jacobus Chapacz, Casper Szoder ista omnes superius descripto uxorati, Georgius Borennius, Joannes monachus de Peplin, Georgius Bruchman relapsus, Mathias Polipergl predicator carmelitarum monachus relapsus, Franciscus Conijes, Joannes Burgarth relapsus, Joannes de Jaroschiwo monachus de Pelplin, Joannes Engelbrecht relapus, Benedictus [s. 6] Wyer, Joannes Cruze ad Sanctam Barbaram capellanus relapsus, Joannes Barbitonsoris relapsus, Ambrosius Hyltfelth, Georgius Gadde, Joanes Gelle, Jacobus Felicis de Lamborg magister scole Sancti Petri, Cristoferus Stargarth relapsus, Arnoldus lector apud fratres minores a Lutero missus, Joannes Ursus de Mariemborg baccalarius, Georgius Korcziemarche laicus predicator ad Sanctam Catherinam [...] Joannes Rogenmolner, Petrus Ernst alias Franke, Jacobus de Mariemborg, Petrus Piccoris, Bartholomeus Lupkerman, Georgius de Knyffen, Thomas in Pruscz plebanus, Bartholomeus Graylych, Venceslaus Kienik. Monachi de Pelplin: Bartholomeus prior, Bernardus medicus, Georgius de Mariemborg, Jacobus de Gdano, Michael Bombeta, Andreas Wydoff, Mathias Tribach, Ignacius Radeke, Henricus Bremen, Joannes Sulczekie de Dersovia, Joannes Baremrayther,

86 Bliższe dane nt. niektórych zakonników mendykanckich wymienionych w spisie zob. ibidem, s. 349-370. 
Joannes Bohemus scolasticus in Puczk. Monachi ordinis minorum: Joannes Croschin, Lazarus Bonaventura Tedkys gwardianus de Nowe, Michael Cossman, Conradus de [Mari] emborg, Henricus Bucholcz, Joannes Barbitonsoris, Bonaventura Calembarz, Cristoferus Modiger Daycemdorff, Georgius Michaelis presbiterii, Joannes Dorneck diaconus, Martinus Berowstei subdiaconus, Baltazar Bornn, Laurencius Ronofforer, Benedictus Vitreator, Andreas Blankyemburg, Mathias Czupkie doleatorus, Daniel Culticze, Gabriel Glasser laici, professi minorum. Ordinis Cartusiensis: Clemens Stubbe, Joannes Olberther, Ambrosius Sawe, Paulus Swartze presbiteri uxorati, Georgius Cantifusoris laicus professus uxoratus. Ordinis Carmelitarum: Hemugnus Krertin, Nicolaus Doleatore subsacrista, Jacobus Lange, Petrus Messe sartor, Casper Doberko, Augustinus Ceriari quondam prior, presbiterii, Martinus quondam procurator, Georgius Ffyerth, Georgius Helle, Andreas Hawestitez, Petrus Gyerbye, Matheus Serick, Joannes Cassuba, Georgius Culwicz, Martinus Czaronita, Joannes, Joachim, Felix presbiteri, diaconi, accoliti et laici professi carmelitarum. Moniales professe eiusdem ordinis: Dorothea Fresse, Anna Strynherth de Stolp, Margaretha [s. 7] Grette, Barbara Pelcze, Anna Czyge, Catherina Bastman, Anna Fleyschowersche, Catherina Brugenslutersche, Margarita Hanshausche, Anna Solaprosche. Ordinis Sancte Brigitte: Joannes Harwnik moniales duxit Joannes Wysiag professus laicus moniales duxit. Moniales eiusdem ordinis: Lucia Kreczmersche abbatissa, Elizabeth Wyssowersche, Brigitta Manthsche, Anna Samelanthsche, Elizabeth Garlachsche, Anna Bornn, Barbara Krote, Gertrudis Heysse. Moniales de Zukow: Anna Tribus, Dorothea Smalcze [...]

\section{Bibliografia}

\section{Źródła archiwalne}

Archiwum Generalne OO. Karmelitów w Rzymie: II Polonia, Commune 1, Marcin Behm, Compendium libri Provinciae, 1677 r.

Archiwum Państwowe w Gdańsku, Akta miasta Gdańska, Dokumenty i listy do 1525 r., 300, D/46, nr 64

\section{Źródła drukowane}

Acta capitulorum Provinciae Poloniae Ordinis Praedicatorum, vol. 1: 1225-1600, ed. R. F. Madura, Roma 1972 
Acta Tomiciana. Tomus octavus decimus epistolarum, legationum, responsorum, actionum et rerum gestarum. Serenissimi Principis Sigismundi Primi Regis Polonie et Magni Ducis Lithuanie, t. 8, wyd. A. T. Działyński, L. Koenig, Poznań 1876

Aus ungedruckten Franziskanerbriefen des XVI. Jahrhunderts, hrsg. L. Lemmens, Münster i. W. 1911

Bernt Stegmann's Chronik vom Aufruhr 1525, w: Scriptores rerum Prussicarum, Bd. 5, hrsg. Th. Hirsch, s. 544-591

Briefe und Urkunden des XVI. Jahrhunderts zur Geschichte der sächsischen Franziskaner, hrsg. L. Lemmens, „Beiträge zur Geschichte sächsischen Franziskanerprovinz", 4/5, 1911/1912, s. 44-62

Rywalizacja katolików z luteranami o kościót św. Mikotaja w Elblagu 1520 -1621. Źródta do dziejów reformacji w Prusach Królewskich, zebr. i oprac. A. Szorc, Olsztyn 2002

S. Grunau's preussische Chronik, Bd. 1, hrsg. M. Perlbach, Leipzig 1876

Urkundenbuch des alten sächsischen Franziskanerprovinzen, t. 1: Die Observantenkustodie Livland und Preussen, t. 2: Die Kustodie Preussen, hrsg. L. Lemmens, Düsseldorf 1913

\section{Opracowania}

Andrews F., The Other Friars. The Carmelite, Augustinian, Sack and Pied Friars in the Middle Ages, Woodbridge 2006

Biskup M., Historia Torunia, t. 2, cz. 1: U schytku średniowiecza i w początkach odrodzenia (1454-1548), Torun 1992

Biskup M., Średniowieczna sieć klasztorów w państwie zakonu krzyżackiego w Prusach (do 1525 r.), „Zapiski Historyczne”, 64, 1999, 1, s. 35-61

Bogucka M., Przemiany spoteczne $i$ walki spoteczno-polityczne, w: Historia Gdańska, t. 2, red. E. Cieślak, Gdańsk 1982

Borawska T., Svenichen (Schweinichen) Aleksander (ok. 1480-1529), franciszkanin, kustosz pruski, kaznodzieja gdański, PSB, 46, 2009, s. 114-115

Borawska T., Życie umystowe na Warmii w czasach Mikotaja Kopernika, Toruń 1996

Borawska T., Rietz H., Aleksander Svenichen (zm. 1529 r.) - franciszkanin $z$ Prus zagubiony $w$ zamęcie reformacji, w: Mikotaj Kopernik $i$ jego świat. Środowisko, przyjaciele, echa wielkiego odkrycia, Toruń 2014, s. 207-221

Buława J., Walki spoteczno-ustrojowe w Toruniu w I potowie XVI wieku, Toruń 1971

Carstenn E., Geschichte der Hansestadt Elbing, Elbing 1937

Chaunu P., Czas reform. Historia religii i cywilizacji (1250-1550), tt. J. Grosfeld, Warszawa 1989

Doelle F., Die Martinianische Reformbewegung in der Sächsischen Franziskanerprovinz (Mittel- und nordostdeutschland) im 15. und 16. Jahrhundert, Münster 1921 
Freytag H., Die Beziehungen Danzigs zu Wittenberg in der Zeit der Reformation, „Zeitschrift des Westpreussischen Geschichtsvereins”, 38, 1898, s. $1-114$

Gause F., Die Geschichte der Stadt Königsberg in Preussen, Bd. 1, Köln-Graz 1965

Glemma T., Dzieje stosunków kościelnych w Toruniu, w: Dzieje Torunia. Praca zbiorowa z okazji 700-lecia miasta, red. K. Tymieniecki, Toruń 1933

Hoogeweg H., Die Stifter und Klöster der Provinz Pommern, Bd. 2, Stettin 1925

Kantak K., Franciszkanie polscy, t. 1, Kraków 1937

Kolberg J., Ermland im Kriege des Jahres 1520, „Zeitschrift für die Geschichte und Altertumskunde Ermlands", 15, 1905, s. 1-208, 481-704

Kopiczko A., Reformacja na Warmii - uwarunkowania i zakres oddziatywania (do 1530 r.), w: Dysydenci czy decydenci? Protestanci w obu częściach Prus i Koronie w XVI-XVIII wieku, red. W. Zawadzki, Elbląg 2018, s. 85-106

Kościelak S., Katolicy w protestanckim Gdańsku od drugiej potowy XVI do końca XVIII wieku, Gdańsk 2012

Kratochwil Z., Augustianie w Chojnicach (1356-1819), „Rocznik Gdański”, 49, 1989, 1, s. 26-32

Kubicki R., Franciszkanie $w$ Gdańsku - zaplecze spoteczne klasztoru oraz jego zwiazki z miastem w XV i pierwszej połowie XVI w., „Nasza Przeszłość,, 115-116, 2011, s. 163-182

Kubicki R., Próby reformy konwentu gdańskiego dominikanów na tle reformy innych klasztorów mendykanckich Prus Królewskich w XV w., w: Ecclesia semper reformanda. Kryzysy i reformy średniowiecznego Kościota, red. T. Gałuszka, T. Graff, G. Ryś, Kraków 2013, s. 515-534

Kubicki R., Die Rolle der Bettelorden im Ordensland Preußen, w: Cura animarum, Seelsorge im Deutschordensland des Mittelalters, hrsg. S. Samerski, Köln-Weimar-Wien 2013 (Forschungen und Quellen zur Kirchen- und Kulturgeschichte Ostdeutschlands, Bd. 45), s. 74-91

Kubicki R., Środowisko dominikanów kontraty pruskiej od XIII do potowy XVI wieku, Gdańsk 2007

Kubicki R., Zakony mendykanckie w Prusach Krzyżackich i Królewskich od XIII do potowy XVI wieku, Gdańsk 2018

Kunzelmann A., Geschichte der deutschen Augustiner-Eremiten, t. 5: Die Sächsisch-Thüringische Provinz und die Sächsische Reformkongregation bis zum Untergang der Beiden, Würzburg 1974

Maciejewski T., Wilkierze miasta Torunia, Toruń 1997

Maercker H., Eine polnische Starostei und ein preussischer Landrathskreis. Geschichte des Schwetzer Kreises 1466-1873, „Zeitschrift des Westpreußischen Geschichtsvereins", 19, 1888, s. 1-597

Małłek J., Początki protestantyzmu $w$ Prusach Książęcych (sekularyzacja państwa zakonu krzyżackiego w Prusach a problem ponownej ewangelizacji), w: idem, 
Opera selecta, t. 4: Reformacja i protestantyzm $w$ Polsce i Prusach (XVI$-X X$ w.), Toruń 2012, s. 230-240

Małłek J., Rozwój reformacji na Pomorzu, w: idem, Opera selecta, t. 4: Reformacja i protestantyzm w Polsce i Prusach (XVI-XX w.), Toruń 2012, s. 120-132

Moorman J., A History of the Franciscan Order from its Origins to the Year 1517, Oxford 1968

Możdżen J., The Beginnings of the Reformation in the Light of Gdansk and Königsberg Chroniclers of the First Half of the $16^{\text {th }}$ Century, „Zapiski Historyczne", 82, 2017, 1, s. 71-96

Możdżeń J., Die Vision der fortschreitenden Reformation in Preußen aus der Sicht des Dominikaners Simon Grunau (*1455-1465/1470-+1529/1530), „Biuletyn Polskiej Misji Historycznej. Bulletin der Polnischen Historischen Mission”, 7, 2012, s. 361-387

Myszka Ł., Dominikanie w Toruniu od XVI do XIX wieku. Katolicki zakon $w$ protestanckim mieście, Kraków 2015 (Studia i Źródła Dominikańskiego Instytutu Historycznego w Krakowie, t. 15)

Nowak Z., Svenichen Aleksander, w: Stownik biograficzny Pomorza Nadwiślańskiego, t. 4, red. Z. Nowak, Gdańsk 1997, s. 301-302

Nyhus P. L., The Franciscan Observant Reform in Germany, w: Reformbemühungen und Observanzbestrebungen im spätmittelalterlichen Ordenwesen, hrsg. K. Elm, Berlin 1989 (Berliner Historische Studien, Bd. 14, Ordenstudien, 6), s. 207-217

Pawlak M., Reformacja i kontrreformacja. Kościoty i wyznania, w: Historia Elblaga, t. 2, cz. 1, red. A. Groth, Gdansk 1996, s. 173-181

Poschmann A., Das Augustinerkloster in Rössel, „Zeitschrift für die Geschichte und Altertumskunde Ermlands", 24, 1932, s. 81-189

Saak E. L., Martin Luther and the Monastic World of the Later Middle Ages, w: Oxford Research Encyclopedia of Religion, http://religion.oxfordre.com/ (2 II 2017)

Schmidt P., Die Gedenkbücher der Danziger Trinitatiskirche, „Mitteilungen des Westpreussischen Geschichtsvereins", 5, 1906, 4, s. 72-74

Schmidt P., Pater Dr. Alexander, ein Nachtrag zur Geschichte der Danziger Trinitatiskirche, „Zeitschrift des Westpreussischen Geschichtsvereins”, 44, 1902, s. 217-224

Schmidt P., Die St. Trinitatis=Kirche zu Danzig nach Vergangenheit und Gegenwart, Danzig 1901

Simson P., Geschichte der Stadt Danzig, Bd. 2, Danzig 1918

Simson P., Wann hat der Danziger Priester Jakob Knothe geheiratet?, „Mitteilungen des Westpreussischen Geschichtsvereins”, 14, 1915, 1, s. 2-4

Spuren franziskanischer Geschichte. Chronologischer Abriß der Geschichte der Sächsischen Franziskanerprovinzen von ihren Anfängen bis zur Gegenwart, bearb. B. Schmies, K. Rakemann, hrsg. D. Berg, Werl 1999 (Saxonia Franciscana, Sonderband) 
Stamm H.-M., Luthers Stellung zum Ordensleben, Wiesbaden 1980 (Veröffentlichungen des Instituts für Europäische Geschichte Mainz, Bd. 101)

Todd J. M., Reformacja, tł. J. S. Łoś, T. Szafrański, Warszawa 1974

Uth G., Szkic historyczno-biograficzny zakonu augustjańskiego w Polsce, Kraków 1930

Wąs G., Teoria i praktyka życia klasztornego na terenach protestanckich w okresie nowożytnym, w: Kasaty klasztorów na obszarze dawnej Rzeczypospolitej Obojga Narodów i na Śląsu na tle procesów sekularyzacyjnych w Europie, t. 1: Geneza kasaty na ziemiach zaborów austriackiego i rosyjskiego, red. M. Derwich, Wrocław 2014, s. 43-59

Weigel-Schieck P., Landesherren und Observanzbewegung. Studien zur Reformverständnis des sächsischen Provinzialminister Matthias Döring (1427-1461), w: Könige, Landesherren und Bettelorden. Konflikt und Kooperation in Westund Mitteleuropa bis zur Frühen Neuzeit, hrsg. D. Berg, Werl 1998 (Saxonia Franciscana Beiträge zur Geschichte der Sächsischen Franziskanerprovinz, Bd. 10), s. 361-390

Wernicke M. K., Die Augustiner-Eremiten, w: Orden und Klöster im Zeitalter von Reformation und katholischer Reform 1500-1570, Bd. 2, hrsg. F. Jürgensmeier, R. E. Schwerdtfeger, Münster 2006, s. 49-72

Wolgast E., Die Einführung der Reformation und das Schicksal der Klöster im Reich und in Europa, Gütersloh 2015 (Quellen und Forschungen zur Reformationsgeschichte, Bd. 89)

Zdrenka J., Urzędnicy miejscy Gdañska w latach 1342-1792 i 1807-1814. Biogramy, Gdańsk 2008

Zins H., Poczatki reformacji na Warmii, w: idem, W kregu Mikotaja Kopernika, Lublin 1966, s. 124-142

Zins H., Rewolta w Elblagu w 1525 r., w: idem, W kregu Mikotaja Kopernika, Lublin 1966, s. 146-203

Zonenberg S., Kronika Szymona Grunaua, Bydgoszcz 2009

Zonenberg S., Wizerunek heretyka w "Preußische Chronik” dominikanina Szymona Grunaua, w: Persona, gestus habitusque insygnium. Zachowania i atrybuty jako wyznaczniki tożsamości spotecznej w średniowieczu, red. J. Banaszkiewicz, J. Maciejewski, J. Sobiesiak, Lublin 2009, s. 103-116

\section{Mendicants Facing Reformation in Royal and Teutonic Prussia until 1526}

The goal of the article is an attempt to follow the reaction of mendicant communities to the events connected with Luther's theses. This problem is presented based on the example of monasteries in Royal and Teutonic Prussia. As the final date of the study the author chose the year 1526. This date is not a general turning point in the internal history of particular mendicant 
orders, but is accepted with respect to local history of Reformation movement. It is connected with the formal reaction to the activity of Reformation supporters taken by the royal court and the bishops of Warmia and Włocławek. Besides the perspective of the institutional history of particular orders the problem is also presented from the point of view of ordinary monks and their individual decisions and motivations.

It follows from the presented analyses that the crisis, which affected mendicant monasteries in the first years of Reformation movement, had a material impact on their further fate. Even if it did not directly lead to depopulation and abandonment, it weakened them very much by depriving numerous, usually young monks. It was them who took the side of Reformation supporters and were active propagators of Luther's teaching. Situation of local convents also worsened due to the collapse of native religious provinces in the Reich (Franciscans, Observants and the order of Hermits of Saint Augustine). But in a longer perspective the social changes were the most important. Monasteries lost their natural background, that is, town inhabitants, who mostly accepted the new faith and treated convent life with indifference, if not with reluctance. In these conditions only monasteries receiving support from the royal court survived (Dominicans and Carmelites in Gdańsk); and later they relied on Pomerania nobility, the majority of which remained Catholics.

Rafał Kubicki - dr hab., profesor Uniwersytetu Gdańskiego, pracuje w Instytucie Historii tamże. Zainteresowania naukowe koncentruje na historii Kościoła w średniowieczu i okresie nowożytnym, kasatach klasztorów w XIX w., dziejach społeczno-gospodarczych państwa krzyżackiego w Prusach, mieszczaństwie późnośredniowiecznym oraz strukturach wiejskich w średniowieczu i okresie nowożytnym.

Rafał Kubicki - PhD with habilitation, assiociate professor at the University of Gdańsk, Institute of History. Particularly interested in Church history in the Middle Ages and early modern period, dissolution of monasteries in the nineteenth century, socio-economic history of monastic state of the Teutonic Knights in Prussia, late medieval townspeople and rural structures in the Middle Ages and early modern period.

E-mail: rafal.kubicki@ug.edu.pl 